\title{
OPTIMALISASI PENGETAHUAN DAN KETERAMPILAN ABK TENTANG PROSEDUR PENGGUNAAN ALAT-ALAT PEMADAM KEBAKARAN DI KAPAL MT. PEMATANG
}

\author{
Aulia Uyun Asalina ${ }^{a}$, Suherman $^{b}$ dan Sri Purwantini ${ }^{c}$ \\ ${ }^{a}$ Taruni (NIT.50134867.N) Program Studi Nautika PIP Semarang \\ ${ }^{\mathrm{b}}$ Dosen Program Studi Nautika PIP Semarang \\ ${ }^{c}$ Dosen Program Studi KALK PIP Semarang
}

\begin{abstract}
ABSTRAK
Fire drill merupakan program pelatihan yang wajib dilaksanakan di kapal sesuai aturan yang terdapat di dalam buku Safety Of Life At Sea (SOLAS) Chapter III Regulation 9.3.4, dan setiap crew kapal harus mempunyai pengetahuan dan keterampilan dalam pengoperasian alat-alat pemadam kebakaran sesuai aturan Standard Of Training Certification and Watchkeeping For Seafarer (STCW) tabel A-VI/1-2. Tujuan dari penelitian ini yaitu, untuk mengetahui bagaimana pengetahuan dan keterampilan anak buah kapal, selain itu penelitian ini juga bertujuan untuk mengetahui sistem pelatihan yang seharusnya diterapkan sebagai meningkatkan pengetahuan dan ketrampilan anak buah kapal dalam kaitannya dengan prosedur penggunaan alat-alat pemadam kebakaran di kapal MT. Pematang / P.1021. Penelitian ini menggunakan metode deskriptif kualitatif, pengumpulan data dilakukan dengan wawancara, observasi, dokumentasi dan studi pustaka. Hasil penelitian menunjukan bahwa, penyebab utama kegagalan pelaksanaan fire drill di kapal MT. Pematang / P.1021 adalah kurangnya pengetahuan anak buah kapal terhadap prosedur penggunaan alat-alat pemadam kebakaran, kurangnya kedisiplinan dan rendahnya kesadaran tentang bahaya yang dapat ditimbulkan. Upaya-upaya yang diterapkan untuk meningkatkan pengetahuan dan keterampilan awak kapal dalam kaitannya dengan alat-alat pemadam kebakaran di kapal MT. Pematang / P.1021 adalah dengan melaksanakan fire drill secara reguler minimal 1 kali sebulan sesuai aturan yang terdapat di dalam buku Safety Of Life At Sea, safety movie, familiarisasi alat-alat modern dan solas training, harus dioptimalkan oleh anak buah kapal.
\end{abstract}

Kata Kunci : pengetahuan dan keterampilan, ABK, alat-alat pemadam kebakaran

\section{PENDAHULUAN}

Indonesia merupakan negara maritim atau kepulauan terbesar di dunia, 2/3 wilayahnya merupakan wilayah lautan. Indonesia juga sebagai negara yang mempunyai banyak pulau. Lima pulau terbesar di Indonesia adalah Pulau Jawa, Pulau Kalimantan, Pulau Sulawesi, Pulau Sumatera, dan Pulau Papua. Jumlah pulau di Indonesia menurut data Departemen Dalam Negeri Republik Indonesia tahun 2004 adalah sebanyak 17.504 buah. 7.870 pulau diantaranya telah mempunyai nama, sedangkan 9.634 pulau belum memiliki nama. Pulau satu dengan pulau yang lain dipisahkan oleh laut. Sarana transportasi untuk menghubungkan pulau satu dengan pulau yang lain dibutuhkan transportasi laut yaitu kapal.

Transportasi berasal dari kata "transportation", dalam Bahasa Inggris yang memiliki arti angkutan, atau dapat pula berarti suatu proses pemindahan manusia atau barang dari suatu tempat ke tempat lain dengan menggunakan suatu 
Optimalisasi Pengetahuan dan Keterampilan ABK Tentang Prosedur Penggunaan Alat-Alat Pemadam Kebakaran Di Kapal MT. Pematang

Aulia Uyun Asalina ${ }^{\mathrm{a}}$, Suherman ${ }^{\mathrm{b}}$ dan Sri Purwantini ${ }^{\mathrm{c}}$

alat bantu kendaraan darat, laut, maupun udara. Transportasi laut adalah pemindahan barang/sesuatu/orang dari pelabuhan tolak menuju pelabuhan tiba menggunakan kapal.

Sarana transportasi yang paling banyak dibutuhkan ialah alat transportasi laut berupa kapal. Karena Indonesia merupakan negara maritim dan kapal mampu mendistribusikan muatan dalam jumlah yang besar dengan biaya yang murah. Ada berbagai macam jenis kapal yang dibedakan berdasarkan jenis muatan yang dibawa. Salah satu jenis kapal adalah kapal tanker. Sesuai dengan jenis muatannya, tanker dapat dibedakan dalam 3 (tiga) kategori, yaitu : Crude Carriers (CC) yaitu kapal tanker untuk pengangkutan minyak mentah, Black-Oil Product Carriers (BOPC) yaitu kapal tanker mengutamakan mengangkut minyak hitam seperti Marine Fuel Oil (MDF) dan sejenisnya. Light-Oil Product Carriers (LOPC) yaitu yang sering mengangkut minyak petroleum bersih seperti kerosene, avtur, gas oil Reguler Mogas (RMS) dan sejenisnya.

Kapal tanker yang dijadikan sebagai obyek penelitian adalah MT. Pematang / P.1021. Kapal ini dimiliki Pertamina Shipping Company. MT. Pematang adalah kapal tanker, kapal tanker mengangkut muatan minyak yang mudah terbakar. Di bidang pelayaran, terutama dalam hal pengoperasian kapal banyak sekali hal-hal yang harus diperhatikan, khususnya jika dikaitkan dengan tujuan manajemen kapal yang menginginkan tercapainya suatu pengoperasian kapal yang lancar, efektif, efisien dan selamat. Seperti yang diketahui banyak sekali kecelakaan-kecelakaan di atas kapal yang seharusnya tidak perlu terjadi, ataupun kegagalan-kegagalan dalam menanggulangi suatu kecelakaan di atas kapal, yang diakibatkan oleh kesalahan manusia (Human Error). Menurut hasil survei yang dilakukan oleh
Komite Nasional Keselamatan Transportasi (KNKT), diperoleh data sejak tahun 2010-2016. Rilis KNKT per November 2016 menyatakan bahwa dari total 54 kecelakaan, 35\% disebabkan oleh kebakaran kapal. Dan pada awal tahun 2017 terjadi kebakaran kapal Yahro Express di Kepulauan Seribu yang menyebabkan 23 korban tewas dan 17 korban hilang. Menurut informasi yang telah didapat oleh KNKT, penyebab terjadinya kebakaran adalah terjadinya kebocoran pada generator dan hal ini semakin diperparah karena kepanikan crew saat menghadapi keadaan darurat.

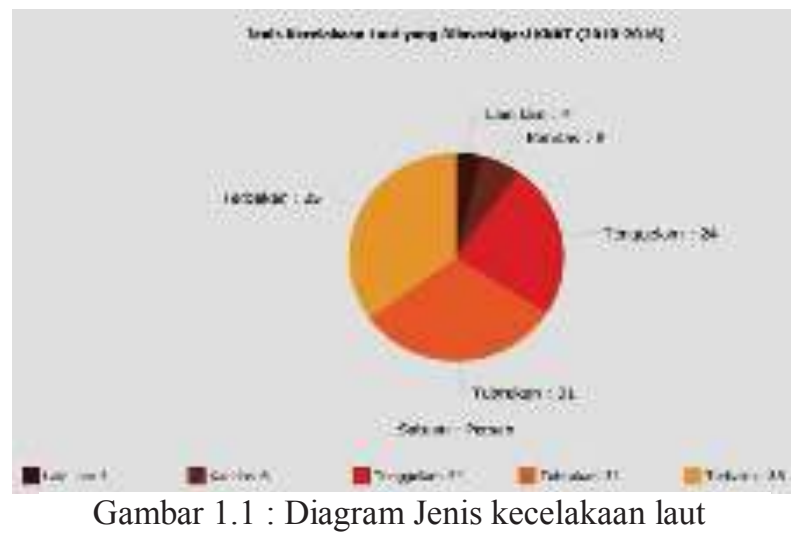

Sumber : knkt.dephub.go.id

Di antara kasus-kasus tersebut di atas, faktor keselamatan merupakan hal yang harus mendapatkan perhatian secara intensif. Keselamatan menjadi sangat penting karena berhubungan dengan jiwa manusia, lingkungan, kapal dan muatan. Oleh karena itu banyak sekali aturanaturan baik nasional maupun internasional seperti : UU No 17 Tahun 2008 tentang Pelayaran, SOLAS 1974 konsolidasi 2014, STCW 1978 amandemen 1995, yang semuanya itu mengatur tentang segala aspek keselamatan baik prosedur maupun cara pengoperasian alat-alat keselamatan. Hal ini juga sesuai dengan semboyan IMO yaitu Safe Secure Efficient on the Clean Sea. 
Berdasarkan latar belakang yang telah diuraikan sebelumnya, maka permasalahan yang akan dibahas dalam penelitian ini adalah sebagai berikut :

1. Bagaimana pengetahuan dan keterampilan $\mathrm{ABK}$ tentang prosedur penggunaan alat-alat pemadam kebakaran?

2. Upaya-upaya apa sajakah yang diperlukan untuk meningkatkan pengetahuan dan keterampilan $\mathrm{ABK}$ tentang prosedur penggunaan alat-alat pemadam kebakaran?

\section{METODOLOGI}

Penelitian ini menggunakan metode deskriptif kualitatif. Menurut Ridwan (2009 : 27) metode deskriptif adalah suatu metode dalam meneliti sekelompok manusia, suatu obyek, suatu set kondisi, suatu sistem pemikiran, ataupun suatu kelas peristiwa pada masa sekarang. Penelitian deskriptif sesuai karakteristik memiliki langkah-langkah tertentu dalam pelaksanaannya, yaitu sebagai berikut :

1. Diawali dengan adanya masalah;

2. Menentukan jenis informasi yang diperlukan;

3. Menentukan prosedur pengumpulan data melalui observasi atau pengamatan;

4. Pengolahan informasi atau data;

5. Menarik kesimpulan.

Menurut Ridwan (2009:27), Tujuan dari penelitian deskriptif adalah untuk membuat deskripsi, gambaran atau lukisan secara sistematis, aktual dan akurat mengenai fakta, sifat serta hubungan antar fenomena yang diselidiki. Metode deskriptif juga ingin mempelajari normanorma atau standar-standar, sehingga penelitian deskriptif ini disebut juga survey normative. Dalam metode deskriptif dapat diteliti masalah normative bersama-sama dengan masalah status dan sekaligus membuat perbandingan antar fenomena. Studi demikian dinamakan secara umum sebagai studi atau penelitian deskriptif. Perspektif waktu yang dijangkau dalam penelitian deskriptif, adalah waktu sekarang, atau sekurang-kurangnya jangka waktu yang masih terjangkau dalam ingatan responden. Di dalam pembahasan nanti akan dipaparkan tentang hasil yang diperoleh baik hal-hal yang bersifat teoritis ataupun yang bersifat praktis, hasil penelitian merupakan hasil pengamatan langsung dan wawancara dengan narasumber yang terkait dengan obyek penelitian.

Metode pengumpulan data dapat diperoleh dari hasil wawancara (interview), hasil observasi, dokumentasi, studi pustaka. Pengumpulan data dimaksudkan untuk memperoleh bahanbahan yang relevan, akurat, dan nyata. Penelitian ini menggunakan metode pengumpulan data lebih dari satu, sehingga dapat saling melengkapi satu sama lain untuk menuju kesempurnaan penelitian.

Dalam penelitian ini penulis mengunakan teknik analisis data deskriptif kualitatif. Teknik analisis data berupa :

1. Reduksi data

Reduksi dalam ini adalah cara memformulasikan teori ke dalam seperangkat konsep yang tinggi tingkatan abstraksinya atas dasar keseragaman kategori dan kawasannya. Data yang ada dipelajari dan dilakukan pembatasan teori sehingga menjadi padat dan berisi dengan mengeluarkan data yang tidak relevan, mengintegrasikan kawasan yang kecil-kecil ke dalam kerangka kategori yang berkaitan.

2. Penyajian Data

Penyajian data dimaksudkan sebagai proses analisa untuk merangkum datadata yang terdapat di lapangan dalam bentuk paparan deskriptif dalam satuan kategori bahan dari yang umum menuju yang khusus. Dengan penyajian data yang tepat diharapkan 
Optimalisasi Pengetahuan dan Keterampilan ABK Tentang Prosedur Penggunaan Alat-Alat Pemadam Kebakaran Di Kapal MT. Pematang

Aulia Uyun Asalina ${ }^{\mathrm{a}}$, Suherman ${ }^{\mathrm{b}}$ dan Sri Purwantini ${ }^{\mathrm{c}}$

supaya pembaca dapat lebih mudah memahami dan mengerti maksud yang akan disampaikan dalam penelitian ini.

3. Penarikan Kesimpulan

Menarik kesimpulan merupakan kemampuan seorang peneliti dalam menyimpulkan berbagai temuan data yang diperoleh selama proses penelitian berlangsung. Dalam penelitian ini peneliti menyimpulkan fakta-fakta yang ada di atas kapal MT. Pamatang / P.1021 berdasarkan hasil observasi dan wawancara kepada para awak kapal.

\section{HASIL PENELITIAN \& PEMBAHASAN}

Dalam pembahasan masalah akan diungkapkan berbagai penyelesaian dari masalah-masalah sebelumnya selain itu pada pembahasan penelitian berdasarkan masalah yang telah dirumuskan akan dikaji lebih mendalam dan lebih detail. Sesuai data-data yang ada, dalam hal ini pembahasan masalah yang dilakukan adalah sebagai berikut :

\section{Pengetahuan dan keterampilan $\mathbf{A B K}$} tentang prosedur penggunaan alatalat pemadam kebakaran.

Kurangnya pengetahuan tentang prosedur penggunaan alat-alat pemadam kebakaran mengakibatkan para ABK tidak terampil dalam mengoperasikan alat-alat pemadam kebakaran hal ini terlihat pada saat dilakukannya fire drill di atas kapal. Dan kurangnya kesadaran ABK terhadap bahaya-bahaya yang dapat terjadi.

\section{a. Pengawasan dari Perwira}

Dalam suatu management peran pengawasan sangatlah penting, untuk mencapai standar yang ditetapkan maka diperlukan pengawasan yang baik, prosedur yang baik, dan tindakan yang baik. Kurangnya pengawasan dari perwira terhadap ABK pada saat dilaksanakan fire drill juga menjadi penyebab $\mathrm{ABK}$ kurang disiplin, dikarenakan mereka mempunyai pemikiran bahwa hal tersebut hanya latihan dan tidak akan ditegur bahkan dikenakan sanksi oleh perwira jika mereka tidak disiplin. Kurangnya pengetahuan yang dimiliki oleh anak buah kapal jelas sangat mempengaruhi keberhasilan dalam melaksanakan tugas-tugasnya di atas kapal, baik tugas rutin maupun tugas yang sifatnya sementara. Meskipun mereka mempunyai pengetahuan yang baik tetapi jika tidak ditunjang oleh keterampilan yang memadai sesuai dengan panduan keselamatan dari perusahaan, maka tetap akan menjadi kendala di dalam pelaksanaan tugas-tugasnya. Oleh karena itu, faktor pengetahuan dan keterampilan ABK kapal harus mendapat perhatian yang besar dari pihak-pihak yang bertanggung jawab dalam hal tersebut.

\section{b. Kurangnya kedisplinan ABK}

Untuk meningkatkan kedisiplinan ABK bukanlah suatu hal yang mudah tanpa disertai usaha-usaha yang keras. Langkah-langkah yang perlu diambil untuk memotivasi ABK meningkatkan pengetahuan dan ketrampilan dalam penggunaan alat-alat pemadam kebakaran memerlukan peranan seorang perwira agar tujuan itu dapat tercapai. Setiap perwira harus selalu memberi contoh dan disiplin kepada anak buah kapal, baik secara lisan maupun tindakan pada saat melaksanakan pekerjaan di atas kapal terutama dalam proses kegiatan latihan atau drill. Seorang 
perwira dalam hal ini terutama Mualim I sebagai safety officer dan Mualim III yang bertanggung jawab kepada Mualim I atas perawatan safety equipment harus mampu menyampaikan kegunaan dan bagaimana cara menggunakan serta menyediakan segala peralatan dan perlengkapan yang diperlukan pada saat melaksanakan latihan kebakaran.

Jika anak buah kapal melakukan suatu tindakan ceroboh dan tidak mematuhi ketentuan-ketentuan yang telah ditetapkan dalam prosedur latihan atau drill. Misalnya bercanda pada saat latihan, tidak memakai alat pelindung yang lengkap, karena ia berpikir bahwa hal itu tidak perlu, hal ini menjelaskan bahwa kesadaran atau disiplin anak buah kurang, dan dapat membahayakan dirinya sendiri maupun rekan kerjanya sehingga perlu tindakan-tindakan untuk penegakan disiplin, seperti memberikan teguran atau sanksi.

Hal ini seperti yang dikemukakan oleh Mualim I dalam hasil wawancara dengan penulis yang menyatakan bahwa, "menurut saya para ABK sedikit banyak sudah mengetahui tentang aturan untuk menomorsatukan keselamatan, tetapi karena kurangnya disiplin dan kesadaran akan bahaya yang dapat ditimbulkan tetap saja masih ada yang bersikap mengabaikan. Maka dari itu perlu dibuat sanksi bagi ABK yang tidak disiplin pada saat drill."

\section{c. Pemberian sanksi yang tegas}

Dalam pemberian sanksi-sanksi kepada ABK yang melanggar peraturan harus bersifat tegas, tidak memandang siapa orangnya, jabatan maupun lamanya masa kerja agar ABK yang menyalahi aturan tidak melakukan pelanggaran lagi dan memperbaiki kesalahannya serta mencegah para ABK yang lain untuk melakukan pelanggaran yang sama.

Tindakan dan sanksi ini dapat berupa suatu tindakan peringatan, dengan membuat suatu pernyataan atau teguran. Jika ABK masih saja tidak memperbaiki kesalahan yang dilakukan maka perwira harus memberikan surat peringatan secara tertulis, tindakan terakhir apabila ABK tidak bisa lagi mematuhi peraturan yang telah ditetapkan adalah menurunkan siapa saja yang melanggar tersebut dari kapal.

Tujuan dari sanksi-sanksi pendisiplinan bersifat positif, mendidik dan mengoreksi. Bukan tindakan negatif yang menjatuhkan ABK yang berbuat salah. Pendisiplinan bertujuan untuk memperbaiki sikap, tindakan dan cara ABK dalam bekerja untuk waktu yang akan datang dan bukannya memberikan hukuman atas kesalahan yang dilakukannya.

Seorang perwira wajib menjalankan tugas dan tanggung jawabnya dengan disiplin, memberi contoh dan pengawasan terbaik dalam mencapai tujuan yang diinginkan. Tujuan itu adalah ABK yang terampil dalam pengoperasian alat-alat pemadam kebakaran:

\section{Upaya-upaya yang diperlukan untuk} meningkatkan pengetahuan dan keterampilan ABK tentang prosedur penggunaan alat-alat pemadam kebakaran.

Sehubungan dengan latihan dan pemahaman alat-alat pemadam kebakaran oleh anak buah kapal, maka dapat dilakukan kerjasama antara Nakhoda dengan anak buah kapal. Nakhoda sebagai pemegang kendali utama menunjuk Mualim 1 sebagai 
Optimalisasi Pengetahuan dan Keterampilan ABK Tentang Prosedur Penggunaan Alat-Alat Pemadam Kebakaran Di Kapal MT. Pematang

Aulia Uyun Asalina ${ }^{\mathrm{a}}$, Suherman ${ }^{\mathrm{b}}$ dan Sri Purwantini ${ }^{\mathrm{c}}$

safety officer untuk melakukan pengarahan-pengarahan kepada semua anak buah kapal mengenai alat-alat pemadam kebakaran, yang dibantu juga oleh Mualim III sebagai pelaksana harian mengenai perawatan alat-alat pemadam kebakaran di atas kapal.

Agar mendapatkan hasil yang lebih baik dengan upaya meningkatkan pengetahuan dan keterampilan tentang prosedur dan tata cara pengoperasian alat-alat pemadam kebakaran di atas kapal, dapat dilakukan dengan cara :

a. Meningkatkan kesadaran anak buah kapal dalam melaksanakan tugas dan tanggung jawab

Mengadakan

pengawasan

langsung kepada anak buah kapal agar melakukan sesuatu pekerjaan yang dapat terlaksana sesuai dengan apa yang diharapkan. Karena bagaimanapun rencana yang akan dilakukan akan gagal dan tidak terlaksana bilamana dalam pekerjaan tersebut tidak diikuti suatu pengawasan.

Seorang pemimpin tentu mengharapkan agar pekerjaan yang dikerjakan sesuai rencana yang telah ditentukan, untuk itu Nakhoda yang dibantu oleh perwira dek dan mesin harus selalu melakukan pemeriksaan, pengecekan atau inspeksi dan tindakan-tindakan lainnya. Bahkan bila perlu menghindari sebelum terjadi kemungkinan adanya penyimpangan terhadap pekerjaan yang dilakukan oleh anak buah kapal. Dan bila hal itu terjadi maka seorang pimpinan di atas kapal harus menempuh langkah perbaikan atau penyempurnaan. Perlu diketahui bahwa secanggih-canggihnya peralatan yang digunakan di atas kapal, jika orang yang mengendalikan peralatan tersebut tidak mentaati peraturan dengan baik atau tidak disiplin pasti hal-hal yang tidak diinginkan akan terjadi.

Dalam hal ini yang paling utama diperbaiki adalah dari manusia itu sendiri. Jika manusia tersebut menyadari akan tanggung jawabnya, maka segala sesuatu yang dikerjakannya dapat diselesaikan tepat waktu. Disiplin adalah salah satu faktor yang sangat penting dalam melaksanakan suatu pekerjaan, dengan adanya kedisiplinan dari anak buah kapal itu sendiri maka dapat menjamin terlaksananya latihan-latihan dalam mengoperasikan alat-alat pemadam kebakaran di atas kapal dengan baik. Dan juga mendapatkan hasil yang baik bagi anak buah kapal itu sendiri.

Pengetahuan awak kapal dapat ditingkatkan dengan cara meningkatkan peran serta perwira dalam hal peningkatan pengetahuan ABK kapalnya, seperti memberikan metode pelatihan yang lebih mudah dimengerti oleh awak kapalnya saat melakukan latihan serta dengan cara menyediakan buku-buku di ruang messroom bagi crew yang ada kaitannya dengan keselamatan seperti buku Solas Training Manual. Sehingga diharapkan dengan cara ini dapat meningkatkan minat membaca dari awak kapal untuk mengetahui lebih dalam mengenai hal-hal yang berkaitan dengan keselamatan di atas kapal.

\begin{tabular}{|c|c|c|}
\hline $\begin{array}{l}\text { Melakukan } \\
\text { mengenai }\end{array}$ & $\begin{array}{l}\text { pemutaran } \\
\text { keselamatan }\end{array}$ & $\begin{array}{r}\text { filn } \\
\text { (Safet. }\end{array}$ \\
\hline Movie) & & \\
\hline Salah & satu & \\
\hline neningka & kesadaran & \\
\hline 1. & $\begin{array}{l}\text { ABK adalah } \\
\text { film }\end{array}$ & \\
\hline 然 & & \\
\hline
\end{tabular}


yang dapat terjadi, dengan pemutaran film ini diharapkan dapat menambah pengetahuan dan keterampilan awak kapal dalam mengoperasikan alat-alat pemadam kebakaran yang ada di atas kapal.

Dalam film ini ditunjukkan bagaimana bahaya yang sering terjadi di atas kapal, dan bagaimana tata cara pengoperasian alat-alat pemadam kebakaran yang baik dan benar, semuanya ditampilkan secara jelas dan dibahas berdasarkan pada prosedur yang benar. Dengan cara ini juga dapat menghilangkan kejenuhan yang dialami selama melakukan pelayaran, dan juga dapat menangkap hal yang diperlihatkan oleh film tersebut yang biasanya berdasarkan oleh fakta yang sering terjadi di atas kapal, bahwa apa yang dilakukannya itu benar atau salah.

$$
\text { Perwira kapal setelah }
$$
melaksanakan pemutaran film ini melakukan diskusi dengan seluruh crew kapal mengenai apa yang telah diperoleh, dan memberikan bimbingan dan penyuluhan kepada seluruh awak kapal serta menanyakan apa yang tidak dimengerti dan mencoba untuk dijelaskan kembali sehubungan dengan apa yang telah dipertunjukkan. Perwira kapal dapat juga melakukan evaluasi dengan melakukan tanya jawab kepada setiap anak buah kapal tentang materi yang telah dipelajari dan dipahami. Dengan mengecek pemahaman anak buah kapal dapat diukur tentang pemahaman anak buah kapal, dengan melakukan pemutaran film tersebut maka dapat meningkatkan pemahaman anak buah kapal dan merupakan sarana yang efektif sebagai penunjang praktek latihan-latihan keselamatan.

\section{c. Memberikan motivasi}

Untuk meningkatkan kemampuan Anak Buah Kapal, dapat dilakukan dengan cara melakukan latihan secara rutin dan terjadwal minimal 1x dalam sebulan untuk melatih keterampilan Anak Buah Kapal dalam pengoperasian alat-alat pemadam kebakaran. Apabila hal tersebut telah dilaksanakan namun tidak mendapat respon yang serius oleh ABK maka Officer bahkan Nakhoda harus memberi sanksi atau punishment yang tegas terhadap ABK tersebut, peringatan secara lisan atau teguran atau peringatan secara tertulis. Dan Sebaliknya Officer atau Nahkoda juga memberi reward atau apresiasi kepada Anak Buah Kapal yang rajin dan terampil dalam prosedur penggunaan alat-alat pemadam kebakaran Sehingga hal ini mampu meningkatkan semangat dan memotivasi crew menjadi lebih baik.

Motivasi crew kapal tentang keselamatan juga dapat diberikan pada saat Safety meeting. Safety meeting merupakan suatu pertemuan yang dilakukan untuk membahas kegiatan-kegiatan keselamatan dan mengevaluasi apabila terjadi kesalahan dalam melaksanakan pekerjaan. Hal ini dilakukan agar upaya keselamatan dalam bekerja dapat terwujud. ABK harus memahami tempat kerja dan peralatan keselamatan yang harus disiapkan sebelum bekerja, sehingga dapat mengurangi resiko kecelakaan yang dapat terjadi. Pentingnya memberikan informasi kepada $\mathrm{ABK}$ adalah agar seluruh ABK berhati-hati dan sadar tentang bahaya yang dapat terjadi sewaktu-waktu ketika sedang bekerja.

Safety meeting mempunyai peran penting sebagai tindakan evaluasi kegiatan yang diadakan agar seluruh 
ABK kapal di atas kapal mendapatkan informasi berkaitan adanya kegiatan yang akan dilakukan, meliputi pengenalan alat-alat keselamatan dan demonstrasi penggunaan alat-alat tersebut dan menyiapkan ABK dalam keadaan darurat.

\section{d. Familiarisasi Peralatan modern safety equipment.}

Perkembangan ilmu pengetahuan terus menerus mengikuti zaman dan perubahan-perubahan mengikuti perkembangan bahkan menghasilkan penemuan-penemuan baru. Alat-alat keselamatan kapal modern dimuat dengan sistem yang baru atau modern. Dengan demikian secara bertahap dan terus menerus akan terjadi perubahan atau perbedaan sistem pengoperasian daripada alatalat tersebut maka familiarisasi sangat diperlukan untuk meningkatkan pengetahuan ABK.

\section{e. Melaksanakan latihan-latihan keselamatan pemadam kebakaran secara regular.}

Drill merupakan latihan yang dilakukan secara terus-menerus atau berulang-ulang, merupakan metode praktis dalam meningkatkan keterampilan. Dalam pelaksanaan drill keterampilan dalam pengoperasian alat-alat pemadam kebakaran sangat menentukan tingkat kesuksesan dan efektifan latihan, maka semakin sering dilaksanakannya suatu latihan peluang ABK menjadi lebih terampil semakin besar.

Melaksanakan latihan-latihan pemadam kebakaran secara reguler sangat efektif untuk dilaksanakan dalam rangka meningkatkan pengetahuan dan keterampilan para anak buah kapal. Latihan keselamatan ini harus tetap dilaksanakan secara regular minimal 1x dalam sebulan. Cara alternatif ini diharapkan dapat mengefektifkan kemampuan dan keterampilan seluruh anak buah kapal dalam mengoperasikan alat-alat pemadam kebakaran yang ada di atas kapal.

Disamping itu, para perwira kapal yang menjadi penanggung jawab atas terlaksananya kegiatan tersebut diharapkan dapat menjalankan tugasnya dengan baik untuk menerangkan hal-hal yang berhubungan dengan pengetahuan serta cara pengoperasian alat-alat pemadam kebakaran secara optimal dan jelas. Dan juga diharapkan seluruh anak buah kapal dapat memahami secara rinci apa yang menjadi tanggung jawab dan juga mengerti apa yang harus dilakukan apabila terjadi keadaan darurat yang sewaktu-waktu bisa terjadi di atas kapal, mengerti bagaimana pengoperasian peralatan keselamatan secara cepat, tepat dan dilakukan sesuai prosedur yang ada di atas kapal.

f. Pemeriksaan terhadap kelengkapan dan kesiapan alatalat pemadam kebakaran.

Petunjuk dan perawatan alat-alat keselamatan pemadam kebakaran di atas kapal haruslah dapat dimengerti dengan mudah, yang sesuai dengan aplikasi-aplikasi di bawah ini (SOLAS 1974 chapter III Reg. 36 : $332-333)$.

\section{KESIMPULAN}

Bedasarkan analisis dan pembahasan pada bab-bab sebelumnya tentang pengetahuan dan ketrampilan $\mathrm{ABK}$ tentang prosedur penggunaan alat-alat pemadam 
kebakaran. Maka dapat ditarik kesimpulan sebagai berikut :

Kurangnya pengetahuan Anak Buah Kapal dalam menggunakan alat-alat pemadam kebakaran dikarenakan kurangnya kesadaran pada anak buah kapal tentang pentingnnya penguasaan terhadap prosedur penggunaan alat-alat pemadam kebakaran, kurang terampilnya anak buah kapal dalam menggunakan alatalat pemadam kebakaran dikarenakan ketidak seriusan dan kurangnya kedisiplinan anak buah kapal pada saat mengikuti latihan di atas kapal kurangnya pengawasan Officer pada saat fire drill dilaksanakan dan kurang tegasnya Officer dalam memberikan reward dan punishment terhadap kedisiplinan anak buah kapal. Sehingga menjadi salah satu faktor tidak maksimalnya pelaksanaan latihan-latihan keselamatan di atas kapal.

Upaya-upaya yang dilakukan untuk meningkatkan pengetahuan dan keterampilan anak buah kapal adalah dengan melaksanakan latihan-latihan atau drill secara reguler (minimal $1 \mathrm{x}$ sebulan) dengan lebih serius.

Melaksanakan solas training sesuai dengan perkembangan teknologi yang semakin modern, melakukan pemeriksaan terhadap kelengkapan dan kesiapan alatalat pemadam kebakaran dan memastikan dalam keadaan baik dan ready to use, memberikan motivasi dan meningkatkan kesadaran $\mathrm{ABK}$ dengan memberikan safety movie kepada anak buah kapal dengan memutarkan film-film tentang keselamatan yang terbaru dan menarik dengan tujuan untuk mengurangi kejenuhan anak buah kapal, mengingatkan kembali tentang keselamatan dan betapa pentingnya latihan-latihan yang serius dan sesuai Peraturan agar anak buah kapal terlatih dan terampil dalam menghadapi keadaan darurat.

Berdasarkan kesimpulan hasil penelitian di atas, maka penulis memberikan saran yang sekiranya dapat bermanfaat dan dapat meningkatkan pengetahuan Dan keterampilan ABK tentang prosedur penggunaan alat-alat pemadam kebakaran di atas kapal MT. Pematang / P.1021. Adapun beberapa saran sebagai berikut :

1. Pada saat anak Buah Kapal baru naik kapal atau pergantian anak buah kapal sebaiknya ABK yang lama atau ABK yang akan digantikan memberikan short training atau familiarisasi tentang tugas dan tanggung jawab yang harus dilakukan di atas kapal sekurangkurangnya 1 sampai 2 hari untuk ratings dan 1 sampai 2 trip untuk officer. Pihak perusahaan sebaiknya memberikan dukungan akan hal tersebut, pihak perusahaan dapat memberikan kebijakan perpanjangan waktu kepada ABK lama sesuai dengan waktu yang dibutuhkan untuk memberikan short training kepada ABK yang menggantikannya, sehingga ABK yang telah ada penggantinya tidak didesak untuk segera sign off.

Karena hal tersebut saling berkaitan, tanpa bantuan atau dukungan dari perusahaan, pihak kapal atau Nakhoda tidak bisa menahan ABK untuk familirisasi lebih detail dan memberikan pelatihan khusus tentang tugas-tugas pada saat dilaksanakannya latihan keselamatan disamping tugas dan tanggung jawab harian sehingga pada saat dilaksanakan drill atau latihan keselamatan di atas kapal Anak Buah Kapal lebih terampil dan optimal dalam pengoperasian alat keselamatan.

2. Nakhoda sebaiknya lebih rutin dan berkala memantau pelaksanaan latihanlatihan keselamatan agar anak buah kapal lebih bersemangat dan disiplin serta mengerti dan memahami tugas dan tanggung jawab masing-masing untuk memastikan kesiapan anak buah kapal kesiapan anak buah kapal dalam menghadapi keadaan darurat dapat 
Optimalisasi Pengetahuan dan Keterampilan ABK Tentang Prosedur Penggunaan Alat-Alat Pemadam Kebakaran Di Kapal MT. Pematang

Aulia Uyun Asalina ${ }^{\mathrm{a}}$, Suherman ${ }^{\mathrm{b}}$ dan Sri Purwantini ${ }^{\mathrm{c}}$

melakukan tindakan-tindakan yang seharusnya dilakukan jika sewaktuwaktu terjadi bahaya kebakaran di atas kapal yang sesuai dengan ketentuan peraturan SOLAS.

\section{DAFTAR PUSTAKA}

Azwar, Saifuddin. 2007. Metode Penelitian. Yogyakarta : Pustaka Pelajar

Cooling, David A. 1990. Fire Prevention And Protection bab 10. Industrial Safety Management And Technology. New Jersey: Prentice Hall

Dunnette. 2006. Ketrampilan Pembukuan. Jakarta : PT. Grapindo prasada

Widoyoko, Eko Putro. 2012. Evaluasi Program Pembelajaran. Yogyakarta : Pustaka Pelajar

Nadler. 1996. Ketrampilan Belajar. Jakarta : Bumi Aksara

Nazir, Moh. 2005. Metode Penelitian. Jakarta : Ghalia Indonesia

Notoatmodjo S. 2007. Promosi Kesehatan Dan Ilmu Perilaku. Jakarta : PT. Rineka Cipta

Ridwan. 2009. Rumus Dan Data Dalam Analisis Statistika Untuk Penelitian. Bandung : Alfabeta

Soekanto. 2007. Sosiologi Suatu Pengantar. Jakarta : PT. Raja Grafindo
Suranto. 2004. Managemen Operasional Angkutan Laut Dan Kepelabuhanan Serta Prosedur Impor Barang. Jakarta : PT. Gramedia Pustaka Utama

Supardi. 2008. Penelitian Tindakan Kelas. Jakarta : PT. Bumi Aksara

Syatori, Nasehudin dan Gozali Nanang. 2012. Metode Penelitian Kuantitatif. Bandung : Pustaka Setia

Sugiyono. 2015. Metode Penelitian Pendidikan (Pendekatan Kuantitatif, Kualitatif, dan $R \& D)$. Bandung: CV. Alfabeta

Suryana. 2010. Metodologi Penelitian Model Praktis Penelitian Kuantitatif dan Kualitatif. Universitas Pendidikan Indonesia

Wiratna. 2014. Metode Penelitian Lengkap, Praktis, Dan Mudah Dipahami. Yogyakarta : Pustaka Baru Press

ICS OCIMF. 1996. ISGOTT (International Safety Guide For Oil Tankers and Terminal, Fourth Edition)

MARPOL (Marine Pollution) 73/78 ANNEX II.

STCW (Standart of Training, Certificate and Wachtkeeping for sea farrers) 1995 Amandement (1997).

SOLAS (Safety Of Life At Sea). 2014. Consolidated Editon.

Undang-Undang RI No. 17 tahun 2008 Tentang Pelayaran. 
Peraturan Menteri No.26/PRT/M/2008

Tentang Persyaratan Teknis Sistem

Proteksi Kebakaran Pada

Bangunan Gedung Dan

Lingkungan.

Badan Diklat Perhubungan. 2000. Fire Prevention and Fire Fighting. Jakarta

2001. Diklat Khusus

Perkapalan Pertamina Advanced Fire Fighting. Jakarta

2001. Diklat Khusus

Perkapalan Pertamina. Basic Safety

Training (pencegahan dan pemadaman kebakaran). Jakarta

Ghazali I. 2005. Aplikasi Analisis Multivariate Dengan Program SPSS BP. Semarang : Universitas Diponegoro

http://www.pertamina.com/1ndex.php/hom e/read/company profile. diakses pada tanggal 25 Oktober 2017. 